\title{
Fermentation of 2,3-butanediol by Pelobacter carbinolicus sp. nov. and Pelobacter propionicus sp. nov., and evidence for propionate formation from $\mathrm{C}_{2}$ compounds
}

\author{
Bernhard Schink \\ Fakultät für Biologie, Universität Konstanz, Postfach 5560, D-7750 Konstanz, Federal Republic of Germany
}

\begin{abstract}
From anaerobic enrichments with 2,3-butanediol as sole substrate pure cultures of new Gram-negative, strictly anaerobic, non-sporeforming bacteria were isolated. Similar isolates were obtained with acetoin as substrate. From marine muds in saltwater medium a short rod (strain Gra Bd 1) was isolated which fermented butanediol, acetoin and ethylene glycol to acetate and ethanol. The DNA base ratio of this strain was $52.3 \mathrm{~mol} \%$ guanine plus cytosine.

From freshwater sediments and sewage sludge, a different type of short rod (strain Ott Bd 1) was isolated in freshwater medium, which fermented butanediol, acetoin, ethanol, lactate and pyruvate stoichiometrically to acetate and propionate. Propanol and butanol were oxidized to the respective fatty acids with concomitant reduction of acetate and bicarbonate to propionate. The DNA base ratio of strain Ott Bd 1 was $57.4 \mathrm{~mol} \%$ guanine plus cytosine. No other substrates were used by the isolates, and no other products could be detected. In cocultures with Acetobacterium woodii or Methanospirillum hungatei, strain Gra Bd 1 also grew on ethanol, propanol, and butanol by fermenting these alcohols to the respective fatty acids and molecular hydrogen. Cytochromes could not be detected in any of the new isolates. Since both types of bacteria can not be affiliated to any of the existing genera and species, the new species Pelobacter carbinolicus and Pelobacter propionicus are proposed. The mechanism of butanediol degradation and propionate formation from acetate as well as the ecological importance of both processes are discussed.
\end{abstract}

Key words: Pelobacter carbinolicus - Pelobacter propionicus - Species description - 2,3-Butanediol - Acetoin Anaerobic degradation - Ethanol metabolism $-\mathrm{CO}_{2}$ reduction - Propionate formation

2,3-Butanediol (Butyleneglycol) is an important end product of fermentations, and is produced mainly by Enterobacteriaceae, Bacillus species, and Lactobacteriaceae. The synthesis proceeds either via condensation of two molecules pyruvate to acetyl lactate, decarboxylation to acetoin and reduction to the diol as in Enterobacteriaceae and Bacillus sp., or by condensation of acetyl phosphate and a thiamine pyrophosphate-bound acetaldehyde residue to diacetyl and subsequent reduction to acetoin and butanediol as in most lactic acid bacteria (Speckmann and Collins 1968). Butanediol dehydrogenase activity is also indüced in strictly

Offprint requests to: $\mathrm{B}$. Schink aerobic bacteria under conditions of oxygen limitation as observed with the knallgas bacterium Alcaligenes eutrophus (Schlegel and Vollbrecht 1980). In nearly all of these bacteria, the butanediol produced is a mixture of all three possible stereoisomers, the $\mathrm{D}(-)$, the $\mathrm{L}(+)$, and the meso-isomer (Long and Patrick 1963). Since butanediol can be chemically converted to butadiene, an important precursor of synthetic rubber, production of butanediol from wheat and barley mashes and waste materials like molasses and whey was actively studied at the end of World War II (Ledingham et al. 1945; Adams and Stanier 1945). Now, these processes gain interest again with rising oil prices (Kosikowski 1979; Palsson et al. 1981; Speckmann and Collins 1982).

For the ecologist the question arose whether butanediol is formed in anaerobic sediments and, if so, how such a highly reduced compound can be degraded anaerobically since it does not accumulate in anaerobic environments. The present paper reports on new bacteria which anaerobically convert butanediol and acetoin to methanogenic substrates.

\section{Materials and methods}

The following strains were isolated in pure culture from enrichment cultures inoculated with mud samples:

Strain Gra Bd 1 from anoxic mud of Canale Grande, a channel in the city of Venice, Italy.

Strain Ott Bd 1 from black anoxic mud of a freshwater creek near Hannover, FRG.

Strain Gö Bd 1 and Ko Bd 5 from anoxic digester sludge of municipal sewage plants at Göttingen and Konstanz, respectively, in Germany. Methanospirillum hungatei strain $\mathrm{M} 1 \mathrm{~h}$ was isolated from digested sludge of the sewage plant at Göttingen, FRG. Acetobacterium woodii strain NZ Va 16 was obtained from R. Bache. A. woodii strain Gra EG 12, DSM 2396 was isolated with ethylene glycol as substrate (Schink and Stieb 1983).

Desulfovibrio vulgaris strain Marburg was kindly provided by Prof. Dr. R. K. Thauer, Marburg. Desulfobulbus propionicus strain 1 pr 3 was a gift of Dr. Fritz Widdel, Konstanz.

\section{Media and growth conditions}

Carbonate-buffered, sulfide-reduced mineral medium with low phosphate content was prepared as described earlier (Widdel and Pfennig 1981; Schink and Pfennig 1982a). Trace element solution SL 7 and vitamin solution (Pfennig 1978) were added to the complete autoclaved medium. The $\mathrm{pH}$ was 
adjusted to 7.2-7.4. All cultivation procedures were essentially the same as described earlier (Schink and Pfennig 1982a).

Growth was followed in $20 \mathrm{ml}$ tubes in a Bausch and Lomb Spectronic 70 spectrophotometer. Some tests for characterization were carried out with commercial media systems (API $20 \mathrm{~A}$, BioMerieux, Nürtingen, FRG). All growth tests were carried out at least in duplicates at $28^{\circ} \mathrm{C}$.

\section{Isolation}

Pure cultures were obtained by repeated application of the agar shake culture method described by Pfennig (1978). Tubes were gassed with $\mathrm{N}_{2} / \mathrm{CO}_{2}$ mixture $(80 \% / 20 \%)$ and sealed with butyl rubber stoppers. Purity was checked microscopically and also by growth tests in complex medium (AC medium, Difco Laboratories, Detroit, MI, USA) with and without addition of $2 \%$ sodium chloride and $10 \mathrm{mM}$ butanediol. Gram staining was carried out according to Magee et al. (1975) without counterstaining. An unidentified Bacillus sp. and Escherichia coli were used as controls.

\section{Chemical analyses}

Sulfide formation was analyzed by the methylene blue method (Cline 1969). Formation of nitrite from nitrate was assayed by azo dye formation with sulfanilic acid and $\alpha$-naphthylamine. Butanediol, other alcohols, volatile fatty acids and methane were assayed by gas chromatographic procedures as described (Schink and Pfennig 1982a).

The DNA base composition was determined with the thermal denaturation method according to DeLey (1970) after extraction according to Marmur (1961).

Cytochromes were assayed in french pressure cell extracts of butanediol-grown cells. Crude extracts as well as membrane fractions prepared by $120 \mathrm{~min}$ centrifugation at $100,000 \times g$ in a Beckman centrifuge were subjected to difference spectroscopy in a Gilford model 250 spectrophotometer.

Protein was determined in crude cell extracts after Beisenherz et al. (1953).

\section{Enzyme assays}

All enzyme assays were carried out with crude French pressure extracts of butanediol-grown cells after spinning down unbroken cell debris at $10,000 \times g$ for $15 \mathrm{~min}$. Hydrogenase was assayed spectrophotometrically with benzyl viologen as electron acceptor after Schink and Schlegel (1979). Acetate kinase and alcohol dehydrogenase were measured by standard methods (Bergmeyer 1974). Butanediol dehydrogenase was assayed as described by Höhn-Bentz and Radler (1978). Acetoin dehydrogenase was measured with the same buffer system as NADH-dependent reduction of diacetyl. Phosphate acetyl transferase was quantified by a procedure modified after Bergmeyer (1974). Increase in absorption at $233 \mu \mathrm{m}$ wavelength was followed in a $1 \mathrm{ml}$ cuvette which contained $0.9 \mathrm{ml} 0.1 \mathrm{M}$ Tris- $\mathrm{HCl}$ buffer, $\mathrm{pH} 7.6,30 \mu 10.1 \mathrm{M}$ acetylphosphate (K-Li-Salt), $30 \mu 110 \mathrm{mM}$ coenzyme $\mathrm{a}$, and $40 \mu \mathrm{l}$ of a suited cell extract dilution. The reaction was started with acetyl phosphate. A Zeiss PM4 spectrophotometer was used for all enzyme assays.

\section{Chemicals}

All chemicals were of reagent grade quality and obtained from Merck, Darmstadt; Serva, Heidelberg; and Fluka, NeuUlm, FRG.

\section{Results}

\section{Enrichment, isolation and enumeration}

$50 \mathrm{ml}$ enrichments in saltwater and freshwater medium with $10 \mathrm{mM}$ 2.3-butanediol as substrate were inoculated with $3-5 \mathrm{ml}$ of anoxic mud from creeks, sewage plants and marine sediments. Gas production started after 4 days and ceased after about 3 weeks. In subcultures on the same media, turbidity developed within 2-5 days. After two further transfers, isolation of butanediol-degrading bacteria was attempted in agar shake series in the presence and absence of excess of Desulfovibrio vulgaris cells and sulfate added as a hydrogen sink. In all cases small lens-shaped, slightly yellowish colonies developed which were again subjected to agar shake series dilution without $D$. vulgaris cells. Pure cultures were isolated from the last positive dilution tubes (strains Gra Bd 1, Ott Bd1, Gö Bd1).

Enumerations of butanediol-degrading bacteria were carried out by the three-tube most probable number technique (American Public Health Association 1969). In mud of Canale Grande, Venice, 1100 cells per ml of mud were counted. The prevailing organisms in the last positive tubes were short rods similar to strain Gra Bd 1, and acetate was the main fermentation product formed to about $20 \mathrm{mM}$ concentration from $10 \mathrm{mM}$ butanediol. In muds of freshwater creeks near Hannover and near Konstanz, 1,500 cells per ml of mud were counted. The prevailing organisms were short rods similar to strain Ott $\mathrm{Bd} 1$. In digested sludge of the sewage plant in Konstanz, 2,400 cells per ml were counted. The prevailing organism was isolated from the last positive tube as strain Ko Bd 5. The fermentation products in the last positive tubes inoculated from freshwater sources were acetate and propionate, and were found in nearly equal molar amounts.

\section{General properties of the new isolates}

All strains grew well in their respective isolation media. Yeast extract was not required but enhanced cell yields slightly. Vitamins and the trace elements molybdenum, tungsten and selenium, although present in the isolation medium, were not required. Addition of phosphate inhibited growth at concentrations higher than $20 \mathrm{mmol} / \mathrm{l}$. The marine isolate Gra Bd 1 thrived well also in freshwater medium, whereas the freshwater isolates were inhibited at salt concentrations higher than $1 \%$. In none of our isolates cytochromes could be detected, neither in redox difference spectra nor in absorption spectra of air-oxidized or dithionite-reduced crude cell extracts or membrane fractions. None of the new isolates reduced nitrate, sulfate, sulfur, thiosulfate, or sulfite.

\section{Characterization of the marine isolate, strain Gra Bd I}

In phase contrast microscopy, cells of strain Gra Bd 1 appeared as nonmotile, straight short rods, $0.5-0.7 \times 1.2-$ $3.0 \mu \mathrm{m}$ in size, with rounded ends, often in pairs (Fig. 1 a). In Indian ink preparations, thin layers of extracellular capsular material were visible (not shown). The Gram reaction was 

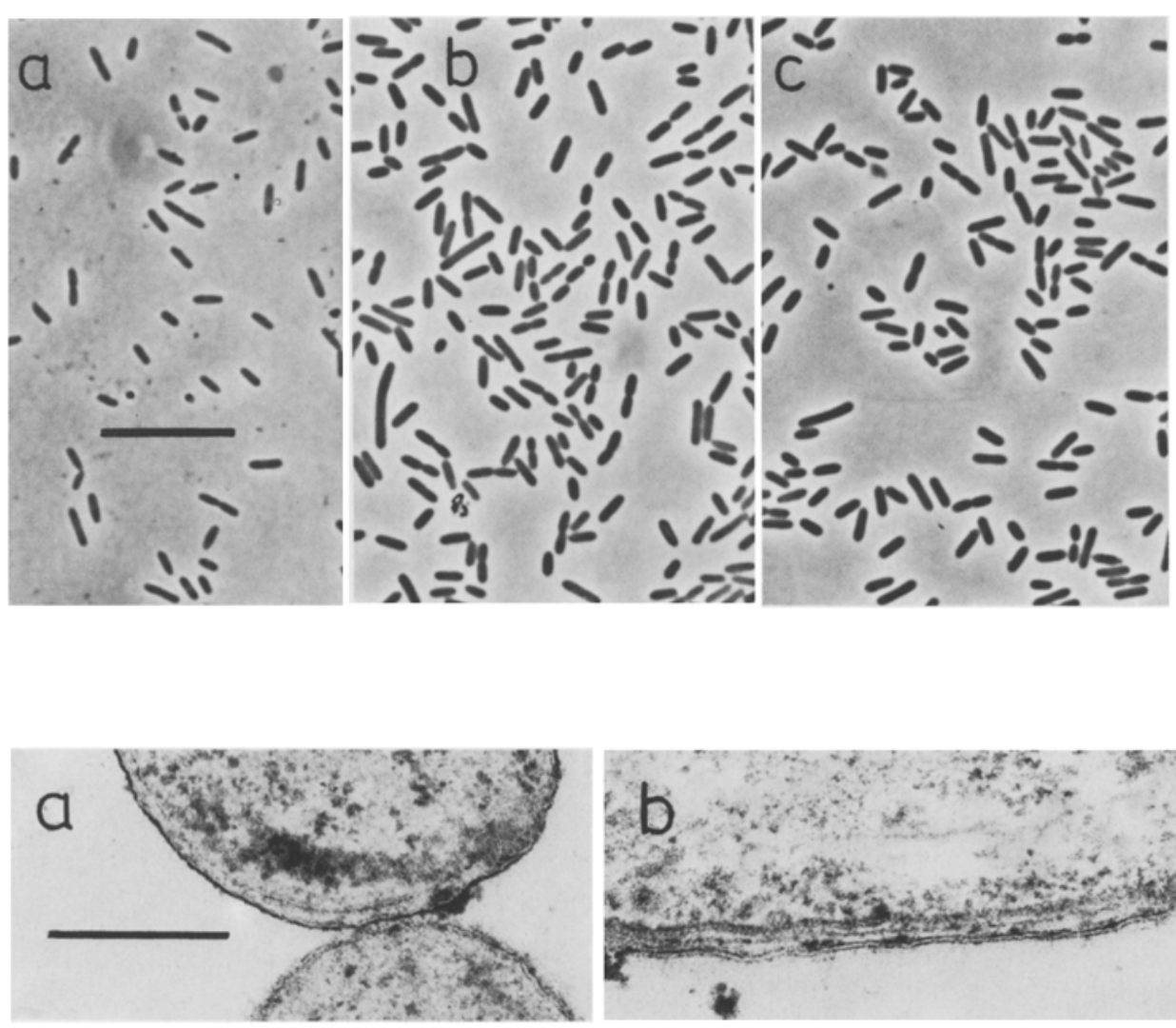

Fig. 1 a-c

Phase contrast photomicrographs of butanediol-fermenting bacterial isolates grown on butanediol. Bar equals $10 \mu \mathrm{m}$. a Pelobacter carbinolicus strain Gra Bd1, b Pelobacter propionicus strain Ott Bd 1, c Pelobacter propionicus strain $\mathrm{Gö} \mathrm{Bd} 1$ negative. Ultrathin sections revealed a multilayered cell wall typical of Gram-negative bacteria (Fig. 2a). Spore formation was never observed. The guanine-plus-cytosine content of the DNA was $52.3 \pm 1.0 \mathrm{~mol} \%$. The only substrates degraded in pure culture were 2.3-butanediol, acetoin, and ethylene glycol (Table 1). They were fermented stoichiometrically to ethanol and acetate (Table 2). The molar growth yield on acetoin was nearly twice as high as on butanediol and ethylene glycol. In cocultures of strain Gra Bd 1 with either Acetobacterium woodii or Methanospirillum hungatei as hydrogen utilizing partners, no ethanol was formed. The growth yield on butanediol increased about twice and growth was also possible on ethanol, propanol and butanol; on the latter two substrates only in the presence of acetate (Table 2). No other substrates were used (see Table 1). The growth curve (Fig. 3 a) shows the dependence of growth and product formation on butanediol utilization. Optimal growth $\left(\mu=0.087 \mathrm{~h}^{-1}\right.$, $t_{\mathrm{d}}=8.0 \mathrm{~h}$ ) was found between 35 and $40^{\circ} \mathrm{C}$, no growth occurred at $10^{\circ} \mathrm{C}$ and $45^{\circ} \mathrm{C}$. The $\mathrm{pH}$ optimum was at $\mathrm{pH}$ $6.5-7.2$, the $\mathrm{pH}$ limits were $\mathrm{pH} 6.0$ and 8.0.

\section{Characterization of freshwater isolates}

Strains Ott Bd 1 and Gö Bd 1 both appeared in phase contrast microscopy as nonmotile, straight rods with rounded ends, $0.5-0.7 \times 1.2-6.0 \mu \mathrm{m}$ in size. Pairs and chains of cells of varying length were often observed (Fig. 1 b, c). In Indian ink preparations, thin layers of capsular material were visible. The Gram reaction was negative. Ultrathin sections revealed a multilayered cell wall typical of Gram-negative bacteria (Fig. 2b). Spores were never found. The guanine-pluscytosine content of the DNA was $57.4 \pm 1.0 \%$. The only
Table 1. Substrates tested for growth of butanediol-fermenting strains of Pelobacter carbinolicus and Pelobacter propionicus

\begin{tabular}{lllll}
\hline $\begin{array}{l}\text { Substrate } \\
(10 \mathrm{mmol} / 1)\end{array}$ & $\begin{array}{l}\text { Pelobacter } \\
\text { carbinolicus } \\
\text { strain }\end{array}$ & $\begin{array}{l}\text { Pelobacter } \\
\text { strains }\end{array}$ & & \\
\cline { 4 - 5 } & Gra Bd 1 & Ott Bd 1 & Gö Bd 1 & Ko Bd 5 \\
\hline 2,3-Butanediol & + & + & + & + \\
Acetoin & + & + & + & + \\
Diacetyl & - & - & - & + \\
Ethanol & $--^{\mathrm{a}}$ & + & + & - \\
Propanol & $-^{\mathrm{a}}$ & $+^{\mathrm{b}}$ & $+^{\mathrm{b}}$ & - \\
Butanol & $-{ }^{\mathrm{a}}$ & $+^{\mathrm{b}}$ & $+^{\mathrm{b}}$ & - \\
Ethylene glycol & + & - & - & - \\
Lactate & - & + & + & \pm \\
Pyruvate & - & + & + & -
\end{tabular}

a Growthwas possible in mixed culture with Acetobacterium woodii or Methanospirillum hungatei

b Growth was only possible in the presence of $10 \mathrm{mM}$ acetate

Substrates not utilized:

- Methanol, isopropanol, glycerol, 1,2-propanediol, 1,2-butanediol, 1,3-butanediol, 1,4-butanediol, $\mathrm{H}_{2} / \mathrm{CO}_{2}+$ acetate

- Formate, acetate, glyoxylate, glycolate, oxalate, malonate, succinate, fumarate, malate, glycerate, oxaloacetate, tartrate, citrate

- Glucose, fructose, mannose, lactose, xylose, rhamnose, maltose, sucrose, cellobiose, mannitol, melezitose, raffinose, sorbose, salicin

- Casamino acids, peptone, yeast extract

- Urea, gelatine or esculin not hydrolyzed No catalase activity

- Substrate concentrations in growth assays were as follows: Alcohols and acids: $10 \mathrm{mmol} / 1$, sugars and others: $0.1 \%(\mathrm{w} / \mathrm{v})$ 
Table 2. Stoichiometry of fermentation and growth yields of marine isolate Pelobacter carbinolicus strain Gra Bd 1 in pure and mixed culture

\begin{tabular}{|c|c|c|c|c|c|c|c|c|c|}
\hline \multirow[t]{2}{*}{ Substrate } & \multirow{2}{*}{$\begin{array}{l}\text { Amount of } \\
\text { substrate } \\
\text { degraded } \\
(\mu \mathrm{mol})\end{array}$} & \multirow{2}{*}{$\begin{array}{l}\text { Cell dry } \\
\text { weight } \\
\text { formed } \\
(\mathrm{mg})^{\mathrm{a}}\end{array}$} & \multirow{2}{*}{$\begin{array}{l}\text { Substrate } \\
\text { assimilated } \\
(\mu \mathrm{mol})^{\mathbf{b}}\end{array}$} & \multicolumn{4}{|c|}{ Products formed ( $\mu \mathrm{mol})$} & \multirow{2}{*}{$\begin{array}{l}\text { Growth } \\
\text { yield } \\
\text { mg/mmol } \\
\text { substrate } \\
\text { utilized }\end{array}$} & \multirow{2}{*}{$\begin{array}{l}\text { Carbon } \\
\text { recovery } \\
\%\end{array}$} \\
\hline & & & & Acetate & Ethanol & $\begin{array}{l}\text { Propio- } \\
\text { nate }\end{array}$ & Methane & & \\
\hline \multicolumn{10}{|l|}{ Pure culture } \\
\hline Butanediol & 200 & 0.72 & 7.2 & 107 & 303 & - & - & 3.60 & 104.3 \\
\hline Acetoin & 200 & 1.39 & 13.9 & 198 & 176 & - & - & 6.95 & 100.4 \\
\hline Ethylene glycol & 200 & 0.72 & 14.4 & 104 & 82 & - & - & 3.60 & 100.2 \\
\hline \multicolumn{10}{|c|}{ Mixed culture with $A$. woodii } \\
\hline Butanediol & 200 & 1.75 & 17.5 & 542 & - & - & - & 8.75 & $100.1^{c}$ \\
\hline Ethanol & 200 & 0.86 & 17.2 & 308 & - & - & - & 4.3 & $108.1^{\circ}$ \\
\hline Propanol & 200 & 0.91 & 18.2 & 89 & - & 204 & - & 4.6 & $105.1^{\circ}$ \\
\hline \multicolumn{10}{|c|}{ Mixed culture with $M$. hungatei } \\
\hline Butanediol & 200 & 1.82 & 18.2 & 392 & - & - & 146 & 9.1 & $102.5^{\mathrm{c}}$ \\
\hline Ethanol & 200 & 0.82 & 16.4 & 186 & - & - & 102 & 4.1 & $101.2^{\circ}$ \\
\hline
\end{tabular}

Experiments were carried out in $20 \mathrm{ml}$ tubes. All figures are means of at least two independent assays

a Cell dry weights were calculated by cell density using the conversion factor $0.1 \mathrm{OD}_{650} \hat{=} 24.2 \mathrm{mg}$ dry weight per 1 , which was obtained by direct determination in $500 \mathrm{ml}$ cultures

b Substrate assimilated was calculated using the formula $\left\langle\mathrm{C}_{4} \mathrm{H}_{7} \mathrm{O}_{3}\right\rangle$ for cell material

c Carbon recovery in mixed cultures was calculated after e.g. the following equations:

$4 \mathrm{CH}_{3} \mathrm{CHOHCHOHCH}+3 \mathrm{HCO}_{3}^{-} \rightarrow 11 \mathrm{CH}_{3} \mathrm{COO}^{-}+5 \mathrm{H}^{+}+4 \mathrm{H}_{2} \mathrm{O}$

$4 \mathrm{CH}_{3} \mathrm{CHOHCHOHCH}+3 \mathrm{HCO}_{3}^{-} \rightarrow 8 \mathrm{CH}_{3} \mathrm{COO}^{-}+5 \mathrm{H}^{+}+3 \mathrm{CH}_{4}+\mathrm{H}_{2} \mathrm{O}$

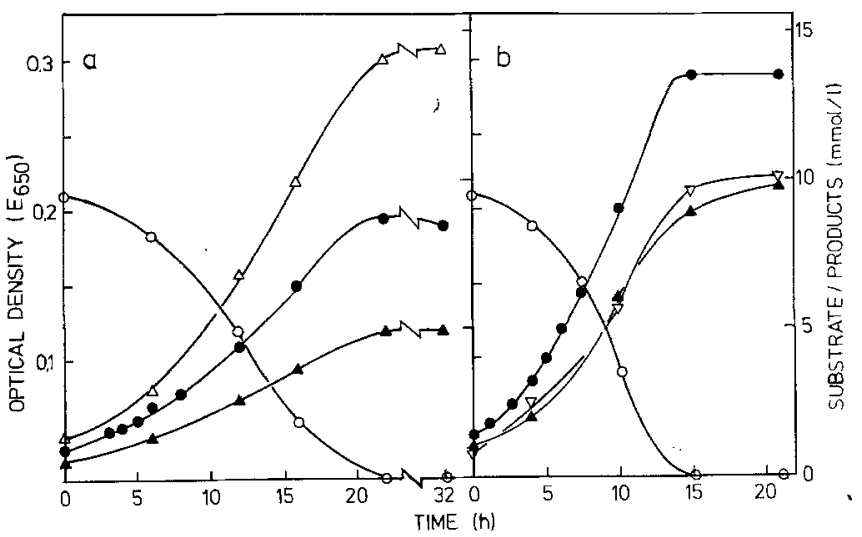

Fig. 3 a and b. Fermentation time course of butanediol-fermenting isolates. Experiments were performed at $30^{\circ} \mathrm{C}$ in $20 \mathrm{ml}$ tubes sealed with Bellco rubber septa. Samples for substrate and product analysis were removed by a syringe at times indicated and the head-spaces were flushed with $\mathrm{N}_{2} / \mathrm{CO}_{2}$ gas mixtures. (•) Optical density, $(\mathrm{O})$ butanediol, $(\Delta)$ acetate, $(\Delta)$ ethanol, $(\nabla)$ propionate. a Pelobacter carbinolicus strain Gra Bd 1, b Pelobacter propionicus strain Ott Bd 1

substrates degraded were 2.3-butanediol, acetoin, ethanol, pyruvate and lactate; in the presence of acetate, also $n$-propanol and $n$-butanol were fermented. The only fermentation products detected were acetate and propionate. Propanol and butanol were oxidized to propionate and butyrate with concomitant reduction of acetate and bicarbonate to propionate (Table 3 ). The highest growth yield was obtained with acetoin as substrate; the yields on lactate and butanediol were equal, whereas on ethanol, propanol and butanol the yields were very small. In carbonate-free medium containing $20 \mathrm{mM}$ potassium phosphate as buffer, strain Ott $\mathrm{Bd} 1$ fermented butanediol to ethanol and acetate in a similar manner as strain Gra Bd 1, however, growth was poor and the butanediol was not utilized sufficiently for stoichiometric calculations.

In coculture experiments with $A$. woodii, $M$. hungatei, or $D$. vulgaris, the fermentation balance of strain Ott $\mathrm{Bd} 1$ was not significantly shifted to more oxidized products, and formation of methane or sulfide was negligible. Oxidation of propionate was not possible in cocultures althouth hydrogenase activity in the range of $0.5 \mathrm{U} / \mathrm{mg}$ protein was detected in crude extracts of butanediol-grown cells.

The growth curve (Fig. $3 \mathrm{~b}$ ) shows the dependence of growth and product formation on butanediol utilization. Optimal growth $\left(\mu=0.144 \mathrm{~h}^{-1} ; t_{\mathrm{d}}=4.8 \mathrm{~h}\right)$ was observed at $33^{\circ} \mathrm{C}$, the temperature limits were $4^{\circ} \mathrm{C}$ and $45^{\circ} \mathrm{C}$. The $\mathrm{pH}$ optimum for growth was between $\mathrm{pH} 7.0$ and 8.0, the limits were $\mathrm{pH} 6.5$ and 8.4.

Strain Ko $\mathrm{Bd} 5$ which was isolated as prevalent butanediol-fermenting organism from anaerobic sewage sludge had similar metabolic properties as the freshwater strains Ott Bd 1 and Gö Bd 1, however, grew much slower $\left(t_{\mathrm{d}} \approx 24 \mathrm{~h}\right)$. It was not characterized further.

Enrichments with acetoin as substrate led to similar isolates as with butanediol in both cases: two ethanol/acetateproducing strains from marine sediments and three propionate/acetate-forming strains from limnic muds. Both types of organisms also exhibited similar substrate utilization spectra as the strains Gra Bd 1 and Ott Bd 1, respectively.

From enrichments on butanediol with pasteurized mud from a freshwater creek, a homoacetogenic Clostridium strain was isolated which will be described in a separate study (Schink 1984). 
Table 3. Stoichiometry of fermentation and growth yields of freshwater isolate Pelobacter propionicus strain Ott Bd 1

\begin{tabular}{|c|c|c|c|c|c|c|c|c|}
\hline \multirow[t]{2}{*}{ Substrate } & \multirow{2}{*}{$\begin{array}{l}\text { Amount } \\
\text { of substrate } \\
\text { degraded } \\
(\mu \mathrm{mol})\end{array}$} & \multirow{2}{*}{$\begin{array}{l}\text { Cell dry } \\
\text { weight } \\
\text { formed } \\
\text { (mg) }\end{array}$} & \multirow{2}{*}{$\begin{array}{l}\text { Substrate } \\
\text { assimilated } \\
(\mu \mathrm{mol})\end{array}$} & \multicolumn{3}{|c|}{ Products formed $(\mu \mathrm{mol})$} & \multirow{2}{*}{$\begin{array}{l}\text { Growth yield } \\
\text { mg/mmol } \\
\text { substrate } \\
\text { utilized }\end{array}$} & \multirow{2}{*}{$\begin{array}{l}\text { Carbon } \\
\text { recovery } \\
\%\end{array}$} \\
\hline & & & & Acetate & $\begin{array}{l}\text { Propio- } \\
\text { nate }\end{array}$ & Butyrate & & \\
\hline Butanediol & 200 & 1.25 & 12.5 & 200 & 198 & - & 6.25 & 105.7 \\
\hline Acetoin & 200 & 1.57 & 15.7 & 267 & 116 & - & 7.85 & 99.6 \\
\hline Ethanol & 200 & 0.29 & 5.8 & 70 & 122 & - & 1.4 & 98.9 \\
\hline Propanola $^{\mathrm{a}}$ & 200 & 0.29 & 4.3 & -120 & 314 & - & 1.4 & 99.4 \\
\hline Butanol $^{a}$ & 200 & 0.33 & 3.3 & -131 & 142 & 195 & 1.65 & 102.8 \\
\hline Lactate & 200 & 1.26 & 16.6 & 66 & 116 & - & 6.25 & 98.3 \\
\hline
\end{tabular}

Calculation of cell dry weights and yields as described in Table 2

a With $200 \mu \mathrm{mol}$ acetate added

a Carbon recovery was calculated on the basis of the fermentation equations given in the Discussion

Table 4. Catabolic enzymes involved in 2,3-butanediol degradation by Pelobacter carbinolicus strain Gra Bd 1 and Pelobacter propionicus strain Ott Bd 1

\begin{tabular}{llll}
\hline Enzyme & $\begin{array}{l}\text { E.C. } \\
\text { number }\end{array}$ & $\begin{array}{l}\text { Specific activity } \\
\left(\mu \mathrm{mol} \cdot \mathrm{min}^{-1}\right. \\
\text { mg protein }\end{array}$ \\
\cline { 3 - 4 } & & Gra Bd 1 $)$ & Ott Bd 1 \\
\hline Butanediol dehydrogenase & $1.1 .1 .4(?)$ & 0.427 & 0.362 \\
Acetoin dehydrogenase & 1.1 .1 .5 & 0.189 & 0.200 \\
Alcohol dehydrogenase & 1.1 .1 .1 & 0.196 & 0.014 \\
Phosphate acetyl transferase & 2.3 .1 .8 & 21.4 & 5.4 \\
Acetate kinase & 2.7 .2 .1 & 0.79 & 2.8 \\
(Propionate kinase) & - & N.D. & 1.13 \\
\hline
\end{tabular}

Assay of enzymes was performed in crude extracts as described in Materials and methods with $3.2-110 \mu \mathrm{g}$ protein per assay

N.D. means not determined

\section{Enzymes involved in butanediol degradation}

In Table 4, the results of enzyme assays in butanediol-grown cells of marine and freshwater isolates are compared. Both contained butanediol dehydrogenase and acetoin dehydrogenase activity. Alcohol dehydrogenase was found in considerable amounts in strain Gra Bd 1 but was negligible in strain Ott $\mathrm{Bd} 1$. Phosphate acetyl transferase and acetate kinase were present in both strains in high activities. In strain Ott $\mathrm{Bd} 1$, also a propionate kinase activity was detected.

\section{Discussion}

\section{Physiology}

The new bacteria described in this paper all degraded 2,3butanediol by cleavage between the C-Atoms 2 and 3, thus releasing two $\mathrm{C}_{2}$ units. The first step in degradation was probably a butanediol dehydrogenase reaction which led to acetoin. In all our experiments, a butanediol preparation was used consisting of all three stereoisomers, namely, about $80 \%$ of the meso- and about $10 \%$ of each the $\mathrm{D}(-)$ and the $\mathrm{L}(+)$ enantiomer (communication by Fluka Chemical Co.). Since we always found complete degradation of the substrate provided, and butanediol dehydrogenases are reported to be strictly stereospecific (Taylor and Juni 1960; Höhn-Bentz and Radler 1978), at least one racemase enzyme for transformation of all three into one suitable enantiomer has to be postulated. The product of the dehydrogenase reaction, acetoin, was also a growth substrate for all our isolates. The further degradation could either proceed by splitting the acetoin molecule into two acetaldehyde residues which would probably be bound to a carrier coenzyme, e.g. thiamine pyrophosphate. If acetoin is oxidized to diacetyl by acetoin dehydrogenase, thiolytic cleavage into an acetaldehyde residue and acetyl-CoA would occur. The results of the enzyme assays do not allow conclusions on which of both pathways is used since the acetoin dehydrogenase activity detected is probably a byfunction of butanediol dehydrogenase. In both cases, cleavage leads to two $\mathrm{C}_{2}$ residues on the redox state of acetaldehyde and two reducing equivalents on the redox level of NAD. The further pathway of $C_{2}$ metabolism differs between the marine and the limnic isolates.

The marine strain Gra Bd 1 disproportionated the acetaldehyde residues to ethanol and acetate, and more ethanol was formed by reduction of acetaldehyde with the electrons derived from the butanediol dehydrogenase reaction. If acetoin was the growth substrate twice as much acetate was formed. The growth yields obtained (Table 2) are in good agreement with the assumption that the formation of acetate by acetate kinase reaction is the only reaction coupled to substrate-linked phosphorylation. On the basis of our data, the yield per mol of adenosine triphosphate synthesized is in the range of $7.0-7.2 \mathrm{~g}$ dry cell matter; this value agrees with observations obtained with other bacteria (Stouthamer 1979). Ethylene glycol was the only further substrate utilized by this strain in pure culture. If a degradation pathway similar to that of Clostridium glycolicum (Gaston and Stadtman 1963) and other anaerobic bacteria (Barker 1972; Toraya et al. 1979) is assumed, again acetaldehyde is an intermediate which is disproportionated to acetate and ethanol. The cell yield was identical with that obtained with butanediol as substrate, and again suggests that acetate kinase was the only energy conserving reaction also in ethylene glycol degradation. The fermentation equations for the substrates mentioned read as follows (all calculations after Thauer et al. 1977; $\Delta \mathrm{Gf}^{\circ}$ values for butanediol, $-321.8 \mathrm{~kJ} / \mathrm{mol}$, and for acetoin, 
$-279.7 \mathrm{~kJ} / \mathrm{mol}$, were calculated by comparison with other alcohols and ketones):

Butanediol:

$\mathrm{CH}_{3} \mathrm{CHOHCHOHCH}_{3}+\frac{1}{2} \mathrm{H}_{2} \mathrm{O} \rightarrow \frac{1}{2} \mathrm{CH}_{3} \mathrm{COO}^{-}+\frac{1}{2} \mathrm{H}^{+}$ $+\frac{3}{2} \mathrm{CH}_{3} \mathrm{CH}_{2} \mathrm{OH}$

$\Delta \mathrm{G}_{\mathrm{o}}^{\prime}=-38.2 \mathrm{~kJ}$

Acetoin:

$\mathrm{CH}_{3} \mathrm{COCHOHCH}_{3}+\mathrm{H}_{2} \mathrm{O} \rightarrow \mathrm{CH}_{3} \mathrm{COO}^{-}+\mathrm{H}^{+}$ $+\mathrm{CH}_{3} \mathrm{CH}_{2} \mathrm{OH}$

$$
\Delta \mathrm{G}_{\mathrm{o}}^{\prime}=-75.4 \mathrm{~kJ}
$$

Ethylene glycol:

$\mathrm{CH}_{2} \mathrm{OHCH}_{2} \mathrm{OH} \rightarrow \frac{1}{2} \mathrm{CH}_{3} \mathrm{COO}^{-}+\frac{1}{2} \mathrm{H}^{+}+\frac{1}{2} \mathrm{CH}_{3} \mathrm{CH}_{2} \mathrm{OH}$ $+\frac{1}{2} \mathrm{H}_{2} \mathrm{O}$

$\Delta \mathrm{G}_{\mathrm{o}}^{\prime}=-83.9 \mathrm{~kJ}$

(Acetaldehyde:)

$\mathrm{CH}_{3} \mathrm{CHO}+\frac{1}{2} \mathrm{H}_{2} \mathrm{O} \rightarrow \frac{1}{2} \mathrm{CH}_{3} \mathrm{COO}^{-}+\frac{1}{2} \mathrm{H}^{+}$

$+\frac{1}{2} \mathrm{CH}_{3} \mathrm{CH}_{2} \mathrm{OH}$

$\Delta \mathrm{G}_{\mathrm{o}}^{\prime}=-37.8 \mathrm{~kJ}$

Thus, strain Gra Bd 1 does not conserve the free energy change of ethylene glycol dehydration to acetaldehyde. This phenomenon was recently also observed for ethylene glycol degradation by Acetobacterium woodii (Schink and Stieb 1983).

In mixed cultures with hydrogen-utilizing methanogenic or homoacetogenic bacteria, strain Gra Bd 1 oxidized all acetaldehyde residues derived from butanediol to acetate thus allowing a cell yield about twice as high as during growth on butanediol in pure culture. In mixed culture, also ethanol, propanol and butanol were oxidized to the respective fatty acids in a similar manner as first shown for the S-organism in the mixed culture Methanobacillus omelianskii (Bryant et al. 1967). A polyethylene glycol-degrading anaerobe recently isolated from the same environment as strain Gra Bd1 degraded primary alcohols in the same manner (Schink and Stieb 1983). Since strain Gra Bd 1 did not degrade any other substrates but those mentioned above it can be concluded that this organism is specialized on the metabolism of acetaldehyde residues and its higher homologues.

The freshwater isolates Ott $\mathrm{Bd} 1, \mathrm{Gö} \mathrm{Bd} 1$, and $\mathrm{Ko} \mathrm{Bd} 5$ oxidized the acetaldehyde residues derived from acetoin cleavage in part to acetate and reduced the other part to propionate. Besides butanediol and acetoin, also ethanol, propanol, butanol, lactate and pyruvate were fermented to the same products. Whereas propionate formation from lactate or pyruvate is a well-known process, the formation of propionate from $\mathrm{C}_{2}$ residues like acetaldehyde, ethanol, or acetate (as in the case of butanol or propanol degradation in the presence of acetate) is a new and interesting phenomenon. Chain elongation of fatty acids was so far only described to proceed in steps of $\mathrm{C}_{2}$-units by reductive condensation of acetate residues as in the case of Clostridium kluyveri (Barker 1937; Bornstein and Barker 1948a, b) or Butyribacterium (Barker and Haas 1944; Zeikus et al. 1980). Recently, Samain et al. (1982) described an ethanol-fermenting bacterium which forms propionate and acetate in a similar manner as our isolates do. In a different study, Desulfobulbus propionicus was shown to ferment ethanol to propionate and acetate in the absence of sulfate (Laanbroek et al. 1982) thus in part turning back the propionate oxidation reaction on the basis of which this bacterium was first enriched and isolated (Widdel and Pfennig 1982). The mechanism of these propionate fermentations has not yet been studied and it remains an open question whether the formation of the C-3 units in these organisms occurs by reversal of one of the classical pyruvate cleavage reactions or via a new so far unknown mechanism. The fact that even acetate can be subject to a reductive carboxylation is of particular interest from a bioenergetical point of view.

The cell yields obtained on the various substrates used are in good agreement with the assumption that also in strain Ott $\mathrm{Bd} 1$ the acetate kinase reaction is the main energy-conserving step in the fermentation process. However, growth is also possible if only propionate is formed as e.g. with propanol as substrate. This observation suggests that under these conditions propionate is formed from propionyl-CoA as a byfunction of phosphate acetyltransferase and acetate kinase (Stadtman 1955; Rose et al. 1954). The cell yield is small under these conditions, probably due to the lack of cytochrome-catalyzed electron transport phosphorylation. Another propionate-forming strict anaerobe that lacks cytochromes was described recently (Schink and Pfennig 1982b). The fermentation equations for strain Ott Bd 1 can be written as follows:

Butanediol:

$\mathrm{CH}_{3} \mathrm{CHOHCHOHCH}+\mathrm{HCO}_{3}^{-} \rightarrow \mathrm{CH}_{3} \mathrm{COO}^{-}$

$+\mathrm{CH}_{3} \mathrm{CH}_{2} \mathrm{COO}^{-}+\mathrm{H}^{+}+\mathrm{H}_{2} \mathrm{O}$

$$
\Delta \mathrm{G}_{\mathrm{o}}^{\prime}=-100.42 \mathrm{~kJ}
$$

Acetoin:

$$
\begin{array}{rr}
\mathrm{CH}_{3} \mathrm{COCHOHCH}_{3}+\frac{2}{3} \mathrm{HCO}_{3}^{-} \rightarrow \frac{4}{3} \mathrm{CH}_{3} \mathrm{COO}^{-} \\
+\frac{2}{3} \mathrm{CH}_{3} \mathrm{CH}_{2} \mathrm{COO}^{-}+\frac{4}{3} \mathrm{H}^{+} \\
\Delta \mathrm{G}_{\mathrm{o}}^{\prime}=-116.9 \mathrm{~kJ}
\end{array}
$$

Ethanol:

$$
\begin{aligned}
& \mathrm{CH}_{3} \mathrm{CH}_{2} \mathrm{OH}+\frac{2}{3} \mathrm{HCO}_{3}^{-} \rightarrow \frac{1}{3} \mathrm{CH}_{3} \mathrm{COO}^{-} \\
& +\frac{2}{3} \mathrm{CH}_{3} \mathrm{CH}_{2} \mathrm{COO}^{-}+\frac{1}{3} \mathrm{H}^{+}+\mathrm{H}_{2} \mathrm{O}
\end{aligned}
$$

$$
\Delta \mathrm{G}_{\mathrm{o}}^{\prime}=-41.5 \mathrm{~kJ}
$$

Propanol:

$$
\begin{aligned}
& \mathrm{CH}_{3} \mathrm{CH}_{2} \mathrm{CH}_{2} \mathrm{OH}+\frac{2}{3} \mathrm{CH}_{3} \mathrm{COO}^{-}+\frac{2}{3} \mathrm{HCO}_{3}^{-} \\
& \rightarrow \frac{5}{3} \mathrm{CH}_{3} \mathrm{CH}_{2} \mathrm{COO}^{-}+\frac{1}{3} \mathrm{H}^{+}+\mathrm{H}_{2} \mathrm{O}
\end{aligned}
$$$$
\Delta \mathrm{G}_{\mathrm{o}}^{\prime}=-39.1 \mathrm{~kJ}
$$

The product analyses (Table 3 ) agree with these equations. Coculture experiments gave no indications for shifts in the fermentation pattern by interspecies hydrogen transfer, although hydrogenase activity was detected in sufficient amounts. 


\section{Ecology}

At present it remains an open question whether butanediol or its oxidation products acetoin and diacetyl play a significant role in anoxic environments. High amounts of butanediol, acetoin and diacetyl are produced during lactic acid fermentation of plant material and milk products at low $\mathrm{pH}$ (Long and Patrick 1963; Kosikowski 1979). Diacetyl was shown recently to have strong antimicrobial effects, especially on Gram negative bacteria (Jay 1982). Thus, even if only traces of these compounds are formed in anoxic environments as a byproduct of lactic acid formation, bacteria capable of anaerobic degradation of these compounds have to be postulated in order to prevent accumulation to toxic concentrations.

Enumerations of butanediol-degrading anaerobic bacteria in this study gave numbers in the range of $1,000-2,500$ per $\mathrm{ml}$ of wet materials in marine and limnic sediments as well as in anaerobic sewage sludge. The prevailing bacteria were metabolically similar to those described in this paper as proven by identification of fermentation products in the last postive enumeraton tubes. Thus, in marine environments, butanediol if produced is mainly converted to acetate since ethanol is not formed in the presence of hydrogen-consuming bacteria. The butanediol-degrading bacteria could also play an important role in syntrophic ethanol oxidation in this environment; the total number of ethanol-oxidizing bacteria in the same marine sediment was $2,400 / \mathrm{ml}$ (Schink, unpublished). In freshwater sediments and sewage sludge, the prevailing butanediol-degrading anaerobes converted butanediol to acetate and propionate, and this fermentation pattern was not altered in cocultures with hydrogenconsuming bacteria. Thus, butanediol and acetoin decomposition can contribute to formation of propionate in freshwater sediments. As shown with pure culture studies in the present study, also ethanol and even acetate could be converted to propionate. Since the numbers of propionate-forming butanediol- and ethanol-degrading bacteria $(1,500 / \mathrm{ml})$ are in the same order of that of total ethanol degraders in the same sediment $(2,100 / \mathrm{ml}$; Schink, unpublished) propionate formation from ethanol may be an important reaction in ethanol degradation in freshwater sediments.

The formation of propionate from acetate and other $\mathrm{C}_{2}$ units by our freshwater isolates and other physiologically similar bacteria described recently (Samain et al. 1982; Laanbroek et al. 1983) is of major ecological interest and is probably also involved in the formation of propionate from hydrogen and carbon dioxide by mixed anaerobic populations (Goldberg and Cooney, 1981). Chain elongations of fatty acids in pure bacterial cultures so far only occurred in steps of $\mathrm{C}_{2}$-units and the formation of propionate from acetate remained enigmatic. The new reaction deserves interest also as another means of utilizing carbon dioxide as an electron acceptor under anaerobic conditions which is different from the well-known homoacetate fermentation and methane formation processes. The ecological significance of this reaction remains to be studied in situ.

\section{Taxonomy}

The new isolates all are Gram-negative, strictly anaerobic, non-sporeforming rods and thus have to be affiliated with the family Bacteroidaceae (Buchanan and Gibbons 1974). However, due to their lack of sugar utilization and their simple growth requirements they can not be attributed to any of the so far described genera. Strain Gra Bd 1 resembles very much the gallic acid-degrading Pelobacter acidigallici (Schink and Pfennig, 1983a) and the polyethylene glycol-degrading Pelobacter venetianus (Schink and Stieb, 1983). All three do not degrade sugars, utilize only very few substrates and mainly those involving $\mathrm{C}_{2}$-units, and the guanine plus cytosine content of the DNA is nearly identical. Therefore, a new species, Pelobacter carbinolicus, is preposed.

Pelobacter carbinolicus sp, nov. car. bi. no' li. cus M. L. adj. referring to carbinols syn. alcohols; carbinolicus metabolizing alcohols.

Rod-shaped cells, $0.5-0.7 \times 1.2-3.0 \mu \mathrm{m}$, with rounded ends, single, in pairs or in chains. Non-motile, Gramnegative, nonsporeforming.

Strictly anaerobic chemoorganotroph. 2.3-Butanediol, acetoin and ethylene glycol utilized for growth and fermented to acetate and ethanol. No other organic substrates utilized. In coculture with hydrogen-consuming bacteria, ethanol, propanol, and butanol are oxidized to the respective fatty acids and hydrogen. Grows in freshwater medium as well as in the presence of $2 \%$ salt. Sulfate, sulfur, thiosulfate, sulfite, or nitrate not reduced. Indole not formed, gelatin or urea not hydrolyzed. No catalase activity, no cytochromes.

Selective enrichment from marine sediments in $\mathrm{NaCl}$ containing mineral media with butanediol or acetoin as sole substrate.

$\mathrm{pH}$ range: $6.0-8.0$, optimum $\mathrm{pH} 6.5-7.2$. $35^{\circ} \mathrm{C}$

Temperature range: $15-40^{\circ} \mathrm{C}$, optimum temperature

DNA base ratio: $52.3 \pm 1.0 \% \mathrm{G}+\mathrm{C}$ (thermal denaturation).

Habitats: anoxic muds of marine origin.

Type strain: Gra Bd 1, DSM 2380, deposited in Deutsche Sammlung von Mikroorganismen, Göttingen.

The freshwater isolates Ott Bd 1, Gö Bd 1, Ko Bd 5 also degrade very few substrates, and acetate and propionate are the fermentation products. Due to the high guanine plus cytosine content of the DNA $(57.4 \%)$ they can not be affiliated with the existing genera of propionate-forming Gram-negative bacteria, namely Propionispira (Schink et al. 1982) or Propionigenium (Schink and Pfennig 1982b). The DNA base ratio resembles that of Selenomonas (Kingsley and Hoeninger 1973), however, the cells lack cytochromes, motility and genus-specific flagellar arrangements. With respect to physiology and DNA base ratio, the new strains very much resemble Desulfobulbus propionicus (Widdel and Pfennig 1982; Laanbroek et al. 1983), however, they do not reduce sulfur compounds, and $D$. propionicus does not grow on butanediol or acetoin. Therefore, until more propionate fermenting bacteria with high $\mathrm{GC}$ ratios are isolated, also strain Ott Bd 1 is attributed to the genus Pelobacter as a new species, $P$. propionicus.

$P$. propionicus sp. nov. pro. pi. ó ni. cus, M.L.n. acidum propionicum propionic acid propionicus forming propionic acid.

Rod shaped cells, $0.5-0.7 \times 1.2-6.0 \mu \mathrm{m}$ in size, with rounded ends, single, in pairs, or in chains. Non-motile, Gram-negative, non-sporeforming.

Strictly anaerobic chemoorganotroph, 2,3-butanediol, acetoin, ethanol, pyruvate and lactate utilized for growth; propanol and butanol are used in the presence of acetate. Propionate and acetate main fermentation products; butanol and propanol are oxidized to the respective fatty acids with 
concomitant reduction of acetate and bicarbonate to propionate. No other substrates utilized; sulfate, sulfite, thiosulfate, sulfur, or nitrate not reduced. Growth requires mineral media with bicarbonate and a reductant.

Indole not formed, gelatine or urea not hydrolyzed. No catalase activity, no cytochromes.

Selective enrichment in bicarbonate-containing freshwater mineral media with butanediol or acetoin as sole substrate.

pH range: $6.5-8.4$, optimum $7.0-8.0$.

Temperature range: $4^{\circ} \mathrm{C}-45^{\circ} \mathrm{C}$, optimum temperature $33^{\circ} \mathrm{C}$.

DNA base ratio: $57.4 \pm 1.0 \% \mathrm{G}+\mathrm{C}$ (thermal denaturation).

Habitats: anoxic muds of freshwater origin; anaerobic sewage sludge digesters.

Type strain: Ott Bd 1, DSM 2379, deposited in Deutsche Sammlung von Mikroorganismen, Göttingen.

Acknowledgements. The author is indebted to Prof. Dr. N. Pfennig for support and valuable criticism, as well as to Waltraud Dilling for determination of DNA base ratios and for electron microscopic characterization in cooperation with Prof. Dr. F. Mayer, Göttingen. Thanks are also due to Barbara Eichler and Elisabeth Kayser for technical assistance. This study was supported by a grant of the Deutsche Forschungsgemeinschaft.

\section{References}

Adams GA, Stanier RY (1945) Production and properties of 2,3butanediol. III. Studies on the biochemistry of carbohydrate fermentation by Aerobacillus polymyxa. Can J Res 23 b:1-9

American Public Health Association Inc, ed (1969) Standard methods for the examination of water and wastewater including bottom sediments and sludge. New York, pp 604-609

Barker HA (1937) The production of caproic and butyric acids by the methane fermentation of ethyl alcohol. Arch Mikrobiol 8:416421

Barker HA (172) Corrinoid-dependent enzymic reactions. Ann Rev Biochem 41:55-90

Barker HA, Haas V (1944) Butyribacterium, a new genus of Gram-positive, non-sporulating anaerobic bacteria of intestinal origin. J Bacteriol 47:301-305

Beisenherz G, Bolze HJ, Bücher T, Czok R, Garbade KH, MeyerArendt E, Pfleiderer G (1953) Diphosphofructose-Aldolase, Phosphoglyceraldehyd-Dehydrogenase, Milchsäure-Dehydrogenase, Glycerophosphat-Dehydrogenase und Pyruvat-Kinase aus Kaninchenmuskulatur in einem Arbeitsgang. $Z$ Naturforsch $8 \mathrm{~B}: 555-577$

Bergmeyer HU (1974) Methoden der enzymatischen Analyse, 3rd ed. Verlag Chemie, Weinheim

Bornstein BT, Barker HA (1948a) The nutrition of Clostridium kluyveri. J Bacteriol 55:223-230

Bornstein BT, Barker HA (1948b) The energy metabolism of Clostridium kluyveri and the synthesis of fatty acids. J Biol Chem 172:659-669

Bryant, MP, Wolin EA, Wolin MJ, Wolfe RS (1967) Methanobacillus omelianskii, a symbiotic association of two species of bacteria. Arch Mikrobiol 59:20-31

Buchanan RE, Gibbons NE (1974) Bergey's manual of determinative bacteriology, 8th ed. Williams and Wilkins Co, Baltimore

Cline JD (1969) Spectrophotometric determination of hydrogen sulfide in natural waters. Limnol Oceanogr 14:454-458

De Ley J (1970) Reexamination of the association between melting point, buoyant density and the chemical base composition of deoxyribonucleic acid. J Bacteriol 101:738-754

Gaston LW, Stadtman ER (1963) Fermentation of ethylene glycol by Clostridium glycolicum sp. n. J Bacteriol 85:356-362
Goldberg I, Cooney CL (1981) Formation of short-chain fatty acids from $\mathrm{H}_{2}$ and $\mathrm{CO}_{2}$ by a mixed culture of bacteria. Appl Environ Microbiol 41:148-154

Höhn-Bentz H, Radler F (1978) Bacterial 2,3-butanediol dehydrogenases. Arch Microbiol 116:197-203

Jay JM (1982) Antimicrobial properties of diacetyl. Appl Environ Microbiol 44:525-532

Kingsley VV, Hoeninger I (1973) Growth, structure and classification of Selenomonas. Bacteriol Rev 37:479-521

Kosikowski FV (1979) Whey utilization and whey products. J Dairy Sci 62:1149-1160

Laanbroek HJ, Abee T, Voogd JL (1982) Alcohol conversions by Desulfobulbus propionicus Lindhorst in the presence and absence of sulfate and hydrogen. Arch Microbiol 133:178-184

Ledingham GA, Adams GA, Stanier RY (1945) Production and properties of 2.3-butanediol. I. Fermentation of wheat mashes by Aerobacillus polymyxa. Can J Res $23 \mathrm{~F}: 48-71$

Long SK, Patrick R (1963) The present status of the 2.3-butylene glycol fermentation. Adv Appl Microbiol 5:135-155

Magee CM, Rodeheaver G, Edgerton MT, Edlich RF (1975) A more reliable Gram staining technic for diagnosis of surgical infections. American I Surgery 130:341-346

Marmur J (1961) A procedure for the isolation of deoxyribonucleic acid from microorganisms. J Mol Biol 3:208-218

Palsson BO, Fathi-Afshar S, Rudd DF, Lightfood EN (1981) Biomass as a source of chemical feedstocks: an economic evaluation. Science 213:513-517

Pfennig N (1978) Rhodocyclus purpureus gen. nov. and sp. nov., a ring-shaped, vitamin $\mathrm{B}_{12}$-requiring member of the family Rhodospirillaceae. Int J Syst Bacteriol 23:283-288

Rose JA, Grunberg-Manago M, Korey SR, Achoa S (1954) Enzymatic phosphorylation of acetate. J Biol Chem 211:737756

Samain E, Albaniac G, Dubourgier HC, Touzel JP (1982) Characterization of a new propionic acid bacterium that ferments ethanol and displays a growth factor dependent association with a Gram negative homoacetogen. FEMS Microbiol Lett 15:69-74

Schink B (1984) Clostridium magnum sp. nov., a non-autotrophic homoacetogenic bacterium. Arch Microbiol (submitted)

Schink B, Pfennig N (1982a) fermentation of trihydroxybenzenes by Pelobacter acidigallici gen. nov. sp. nov., a new strictly anaerobic, non-sporeforming bacterium. Arch Microbiol 133:195201

Schink B, Pfennig N (1982b) Propionigenium modestum gen. nov. sp. nov., a new strictly anaerobic, nonsporing bacterium growing on succinate. Arch Microbiol 133:209-216

Schink B, Schlegel HG (1979) The membrane-bound hydrogenase of Alcaligenes eutrophus. I. Solubilization, purification, and biochemical properties. Biochim Biophys Acta 567:315-324

Schink B, Stieb M (1983) Fermentative degradation of polyethylene glycol by a new, strictly anaerobic, Gram negative, nonsporeforming bacterium, Pelobacter venetianus sp. nov. Appl Environ Microbiol 45:1905-1913

Schink B, Thompson TE, Zeikus JG (1982) Characterization of Propionispira arboris gen. nov. sp. nov., a nitrogen-fixing anaerobe common to wetwoods of living trees. J Gen Microbiol 128:2771-2779

Schlegel HG, Vollbrecht D (1980) Formation of the dehydrogenases for lactate, ethanol and butanediol in the strictly aerobic bacterium Alcaligenes eutrophus. J Gen Microbiol 117:475481

Speckmann RA, Collins EB (1968) Diacetyl biosynthesis in Streptocuccus diacetilactis and Leuconostoc citrovorum. J Bacteriol 951:174-180

Speckmann RA, Collins EB (1982) Microbial production of 2.3butylene glycol from cheese whey. Appl Environ Microbiol $43: 1216-1218$

Stadtman ER (1955) Phosphotransacetylase from Clostridium kluyveri. In: Colowick SP, Kaplan NO (eds) Methods in enzymology, vol 1. Academic Press, New York, pp 596-599 
Stouthamer AG (1979) The search for correlation between theoretical and experimental growth yields. In: Quayle JR (ed) International review of biochemistry, microbial biochemistry, vol21. University Park Press, Baltimore, pp 1-47

Taylor MB, Juni E (1960) Stereoisomeric specificities of 2,3butanediol dehydrogenases. Bíochim Biophys Acta 39:448457

Thauer RK, Jungermann K, Decker K (1977) Energy conservation in chemotrophic anaerobic bacteria. Bacteriol Rev $41: 100-180$

Toraya T, Honda S, Fukui S (1979) Fermentation of 1,2-propanediol and 1,2-ethanediol by some genera of Enterobacteriaceae, involving coenzyme $\mathrm{B}_{12}$-dependent diol dehydratase. J Bacteriol $139: 39-47$

Widdel F, Pfennig N (1981) Studies on dissimilatory sulfatereducing bacteria that decompose fatty acids. I. Isolation of new sulfate-reducing bacteria enriched with acetate from saline environments. Description of Desulfobacter postgatei gen. nov. sp. nov. Arch Microbiol 129:395-400

Widdel F, Pfennig N (1982) Studies on dissimilatory sulfate-reducing bacteria that decompose fatty acids. II. Incomplete oxidation of propionate by Desulfobulbus propionicus gen. nov. sp. nov. Arch Microbiol 131:360-365

Zeikus JG, Lynd LH, Thompson TE, Krzycki JA, Weimer PJ, Hegge PW (1980) Isolation and characterization of a new, methylotrophic, acidogenic anaerobe, the Marburg strain. Curr Microbiol 3:381-386

Received June 1, 1983/Accepted October 4, 1983 